American Journal of Environmental Sciences 5 (5): 618-624, 2009

ISSN 1553-345X

(C) 2009 Science Publications

\title{
Hybrid Photovoltaic Thermal (PV/T) Air and Water Based Solar Collectors Suitable for Building Integrated Applications
}

\author{
Adnan Ibrahim, Goh Li Jin, Roonak Daghigh, Mohd Huzmin Mohamed Salleh, \\ Mohd Yusof Othman, Mohd Hafidz Ruslan, Sohif Mat and Kamaruzzaman Sopian \\ Solar Energy Research Institute, University Kebangsaan Malaysia, 43600, Bangi, Selangor, Malaysia
}

\begin{abstract}
Problem statement: Experiments have been conducted to investigate the effect of mass flow rates on the electrical, thermal and combined of photovoltaic thermal efficiencies of the hybrid collectors. Approach: Two photovoltaic thermal solar collectors were designed and fabricated. The first collector, known as spiral flow absorber collector, designed to generate hot water and electricity. The second collector, known as single pass rectangular tunnel absorber collector designed to generate hot air and electricity. Both absorber collectors were fixed underneath the flat plate single glazing sheet of polycrystalline silicon PV module. Water was used as a heat transfer medium in spiral flow absorber collector and air for the Single pass rectangular tunnel absorber collector respectively. Results: The experiment results showed that the single flow absorber collector generates combined PV/T efficiency of $64 \%$, electrical efficiency of $11 \%$ and power maximum achieved at $25.35 \mathrm{~W}$. Moreover, Single pass rectangular tunnel absorber collector generated combined PV/T efficiency of 55\%, electrical efficiency of $10 \%$ and maximum power of $22.45 \mathrm{~W}$. Conclusion/Recommendations: The best mass flow rate achieved for spiral flow absorber collector is $0.011 \mathrm{~kg} \mathrm{sec}^{-1}$ at surface temperature of $55 \%$ and $0.0754 \mathrm{~kg} \mathrm{sec}{ }^{-1}$ at surface temperature of $39^{\circ} \mathrm{C}$ for single pass rectangular collector absorber. It was recommended for PV/T system to further improve its efficiency by optimizing the contact surfaces between the solar panel (photovoltaic module) and the tubes underneath and also recommended to use other type of photovoltaic cell such as amorphous silicon cell that posses the black mat surfaces property that will improve it thermal absorption.
\end{abstract}

Key words: Photovoltaic Thermal (PV/T), thermal and electrical efficiency, absorber collectors

\section{INTRODUCTION}

Energy is required in almost every aspect of human activities and development of any nation in this world. Increasing fossil fuel price, energy security and climate change have important bearings on sustainable development of any nation. The increase in fossil fuel prices has created an inflationary pressure in the economic field which influenced the increase in interest rates and investments ${ }^{[1]}$. One of the drastic approaches taken by researchers all over the world is to introduce a backup or replacement source of energy. One of the promising energy is the renewable energy technologies -in this case, solar energy, which commonly known as Photovoltaic technology (PV). The photovoltaic technology has its own advantages comparing to other sources, such as, operate in noiseless mode, totally clean and green energy, highly credibility system with life span expectation between 20-30 years and very low maintenance system. There are many applications of photovoltaic technology, such as, for heating purposes for water and space, solar drying and building integrated skins (facades). In heating, photovoltaic module is combined with solar thermal absorber collector to produce a hybrid system. It is known fact that the efficiency conversion of solar energy to electrical energy using photovoltaic cells is limited by several factors. Firstly, conversion efficiency falls as the temperature of the photovoltaic cells rise and secondly, the photovoltaic cells are only responsive to a portion of solar spectrum, which is equivalent or higher than the band gaps of the solar radiation. This is one of the main reason that make the usage of photovoltaic in tropical countries is less choice ${ }^{[2]}$.

Photovoltaic Thermal technology (PV/T) has been developed since 70's. Basically the solar energy technology can be broadly classified into two systems; photovoltaic energy system and thermal energy system. The term PV/T refers to solar thermal collectors that use PV cells as an integral part of the absorber plate.

Corresponding Author: Adnan Ibrahim, Solar Energy Research Institute, University Kebangsaan Malaysia, 43600, Bangi, Selangor, Malaysia Tel: +603 89214596 Fax: +603 89214593 
The system generates both thermal and electrical energy simultaneously. The first air hybrid collector was employed by the University of Delaware. The hybrid collector which was integrated by Böer et al. ${ }^{[3]}$ integrate the solar collector to building roof, known as "Solar One" house. Since the first hybrid collector being studied, variety of studies about the PV/T system has been carried out throughout the world. The studied mostly focusing on the air and water based as the medium to the heat transfer ${ }^{[4-8]}$.

Amongst the PV/T solar collectors that being studied, the most popular is the air type solar collector with photovoltaic module, even though it is most popular, this type of collector has less in usage compared to the water collectors ${ }^{[9]}$. The PV/T solar collector system has been designed to generate the electricity and at the same time to produce hot air and hot water. The hot air and hot water gained can be used for other purposes in low heat temperature processes. Wolf $^{10]}$ analyzed the performance of the combination of heating and photovoltaic power systems for residences using Hottel-Whillier model ${ }^{[11]}$, he analyzed the combination of photovoltaic and thermal flat plate collectors with the traditional hot water system and PV module. He concluded that the system was technically feasible and cost effective. Zondag et al. ${ }^{[12]}$ reviewed various concepts of combined PV-thermal collector technologies by introducing and evaluating nine different designs, ranging from the complicated to the simpler one, in order to investigate the maximum yield. They concluded that the design of the channel below the transparent PV, with PV-on-sheet and tubes design gives the best efficiency overall. Bergene et al. ${ }^{[13]}$ perform theoretical examination of a flat plate solar collector model that integrated with solar cells. They concluded that, the system can produced approximately about $60-80 \%$ efficiency. Huang et al. ${ }^{[14]}$ have developed PV/T system using a polycrystalline solar PV panel, adopted to be combined with a collector plate. They suggested that the collector plate must be directly attached to the PV panel using the thermal grease, for better contact. He et al. ${ }^{[15]}$ recently studied the hybrid PV/T system which used natural convection to circulate the water, adopting a flat-box absorber design. The study shows increasing of daily thermal efficiency up to $40 \%$.

The aim of this study is to study the influence of various mass flow rates to the efficiency of the collectors. This research provides experimental results and could be considered useful to estimate the accuracy of various mass flow rates for both collectors. Results from the results and observation of the experiment, enable us to justify the collectors which are able to convert solar energy simultaneously into electrical energy and thermal energy in such a way that the two processes are compatible and integrated.

\section{Collectors configuration:}

Spiral flow absorber collector: In this experiment, a specially made Spiral flow absorber collector and Single pass rectangular tunnel absorber collector have been designed and evaluated. The Spiral flow, as shown in Fig. 1, is made of rectangular hollow tubes of stainless steel material with dimension of $12.7 \times 12.7 \mathrm{~mm}$.

The tube was connected using a welding method. The absorber collector should have a single unilateral channel for the water to flow in it with the size of $815 \times 628 \mathrm{~mm}$ before it is assembled underneath the standard PV module with the size of $1 \mathrm{~m}$ height and $0.65 \mathrm{~m}$ length. As shown in Fig. 2, the photovoltaic module has been represented as a flat plate single glazing sheet of polycrystalline silicon with single glazing sheet. The Spiral flow absorber collector is designed in the form of continuous coil or tube configured. The spiral coil has at least one inlet and outlet to allow fluid to enter and to exit from coil respectively.

The inlet and the outlet of the spiral coil are arranged further away to the entre point of the spiral. This will allow the water to flow in reversed direction and covered the entire photovoltaic module. Water with lower temperature enters the coil and travel through the spiral coil into the centre point and travel away from the centre point leaving the coil as hot water. The hot water can be consumed or stored for later use. In this way solar radiation energy can be fully utilized.

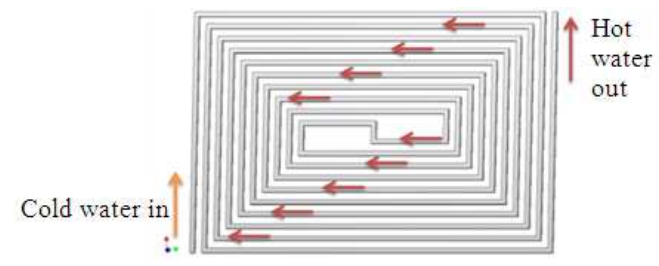

Fig. 1: The design of Spiral flow absorber collector

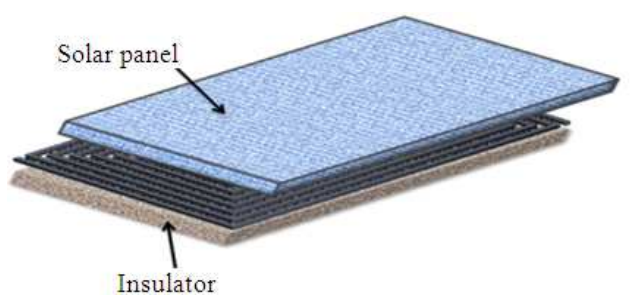

Fig. 2: The perspective view of Spiral flow absorber collector 


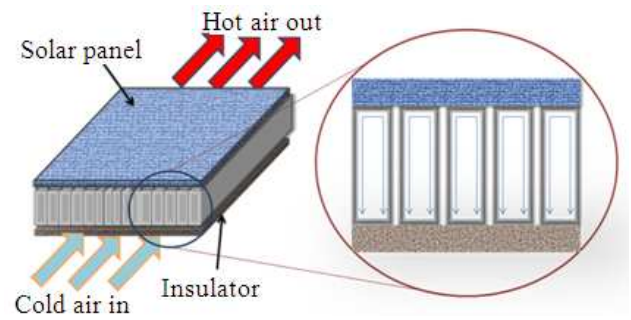

Fig. 3: The design of Single pass rectangular tunnel absorber

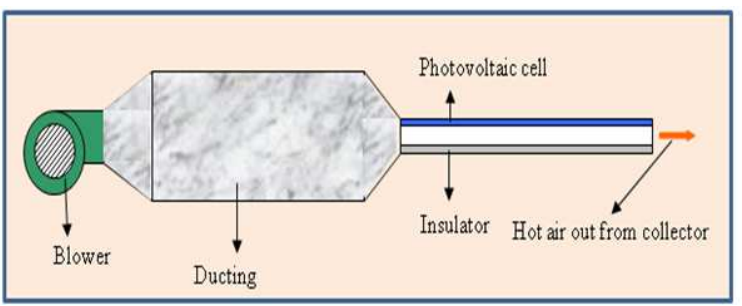

Fig. 4: Blower and photovoltaic thermal collector ducting connection

Single pass rectangular tunnel absorber collector: As shown in Fig. 3, Single pass rectangular tunnel absorber collector is fabricated from 39 units of aluminium hollow rectangular tubes, with the size of $1.2 \times 2.5 \times 120 \mathrm{~cm}$. The tubes are then arranged in parallel, stacking side by side, to form a tunnel configuration.

The tunnel design comprised of $1 \mathrm{~m}$ height and $0.65 \mathrm{~m}$ length and has been inserted underneath the standard PV module. The tunnel rectangular tubes have been placed underneath the PV module act as heat conductor. Once it is place underneath the PV module, an insulator is used to cover the tunnel to prevent heat loss to surrounding. Referring to Fig. 4, ducting has been designed and fabricated and connected to blower. A heater made of 2 halogen lamps was place inside the ducting to stabilize the air temperature that going into the collector.

\section{MATERIALS AND METHODS}

Experimental set-up: In this experiment, a standard solar panel model, which rating at $80 \mathrm{~W}$ power under $800 \mathrm{~W} \mathrm{~m}^{-2}$ solar radiation, is used. As seen in Fig. 5, the solar PV/T collectors are tested under 23 simulator halogen lamps. The experiment was conducted in control environment (constant room temperature of $25^{\circ} \mathrm{C}$ ) and was tested under 5 different mass flow rates. Both collectors are tested with and without the absorbers to compare the differences. Solar radiation from experiment lamps are set approximately at $800 \mathrm{~W} \mathrm{~m}^{-2}$.

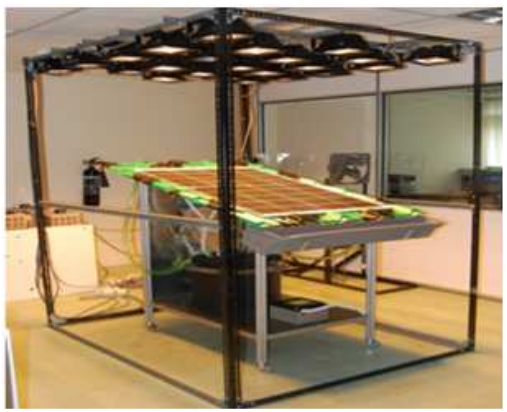

Fig. 5: The solar panel under the halogen lamps simulator

Mass flow rates for Single flow absorber collector are set ranging from $0.004-0.02 \mathrm{~kg} \mathrm{sec}^{-1}$. For Single pass rectangular tunnel absorber collector, the mass flow rates are set ranging from $0.0110-0.0754 \mathrm{~kg} \mathrm{sec}^{-1}$. The tests are carried out by setting the solar radiation to the designated power and once it reaches steady state condition, the medium (water and air) are flowed through the collector absorbers. The parameters measured are: Current, I (A), Voltage, $(\mathrm{V})$, short circuit current, $\mathrm{I}_{\mathrm{sc}}(\mathrm{A})$, open circuit voltage, $\mathrm{V}_{\mathrm{oc}}(\mathrm{V})$ and temperature, $\mathrm{T}\left({ }^{\circ} \mathrm{C}\right)$ are measured every $90 \mathrm{~min}$. Data collected are used to calculate the electrical efficiency and thermal efficiency for both collectors.

\section{RESULTS AND DISCUSSION}

The performance of collectors can be depicted by the combination of efficiency expression ${ }^{[15]}$. It comprised of the thermal efficiency $\eta_{\text {th }}$ and the electrical efficiency $\eta_{\mathrm{e}}$. The total efficiencies, which is known as combined PV/T efficiency $\eta_{\circ}$ is used to evaluate the overall performance of the system:

$$
\eta_{\mathrm{o}}=\eta_{\text {thermal }}+\eta_{\text {electrical }}
$$

The thermal performance $\eta_{\text {th }}$ of the PV/T unit is evaluated for its thermal and photovoltaic performance, as such, the derivation of the efficiency parameters based on the Hottel and Whillier Equations ${ }^{[11]}$ were used. For both absorber collectors efficiency, the fluid and air mass flow rates can be calculating using the equation below:

$$
\dot{\mathrm{m}}=\rho \mathrm{AV}_{\mathrm{av}}
$$

Where:

$\dot{\mathrm{m}}=$ The mass flow rate

$\rho=$ The density of the fluid or air drain input area

$\mathrm{V}_{\mathrm{av}}=$ The fluid or air velocity, determined using voltage regulator and blower in the case of air 
$I_{\mathrm{sc}}$ and $\mathrm{V}_{\mathrm{oc}}$ can be achieved by connecting directly to the multimeter, which later connected directly to the solar panel. $I_{m}$ and $V_{m}$. Where $I_{m}$ and $V_{m}$ are from power maximum, $\mathrm{P}_{\mathrm{m}}$. Power, $\mathrm{P}$ is the result of current, $\mathrm{I}$ (V). The thermal efficiency of the collector can be expressed by ${ }^{[16]}$ :

$$
\eta_{\text {th }}=\frac{\dot{\mathrm{m}} \mathrm{C}_{\mathrm{p}} \Delta \mathrm{T}}{\mathrm{A}_{\mathrm{p}} \mathrm{G}_{\mathrm{T}}} \times 100 \%
$$

Where:

$\dot{\mathrm{m}}=$ Mass flow rate $\left(\mathrm{kg} \mathrm{sec}^{-1}\right)$

$\mathrm{C}_{\mathrm{p}}=$ Specific heat of the collector cooling medium ( $\mathrm{J}$ $\mathrm{kg}^{-1}{ }^{\circ} \mathrm{C}^{-1}$ )

$\Delta=$ Differences between fluid or air outlet temperature $(\mathrm{K}),\left(\mathrm{T}_{\mathrm{o}}\right)$ and fluid or air inlet temperature $(\mathrm{K})\left(\mathrm{T}_{\mathrm{i}}\right)$

$A_{p}=$ Area covered by absorber collector

$\mathrm{G}_{\mathrm{T}}=$ Solar radiation at NOCT (irradiation level $800 \mathrm{~W}$ $\mathrm{m}^{-2}$, wind velocity $1 \mathrm{~m} \mathrm{sec}^{-1}$, ambient temperature at $26^{\circ} \mathrm{C}$ taken every $90 \mathrm{~min}$ )

Performance of electrical efficiency, $\eta_{\mathrm{el}}$ is shown as below:

$$
\eta_{\mathrm{el}}=\frac{\mathrm{I}_{\mathrm{m}} \mathrm{V}_{\mathrm{m}}}{\mathrm{A}_{\mathrm{p}} \mathrm{G}_{\mathrm{T}}} \times 100 \%
$$

Where:

$\mathrm{I}_{\mathrm{m}}=$ The maximum current $(\mathrm{A})$

$\mathrm{V}_{\mathrm{m}}=$ Maximum voltage $(\mathrm{V})$

The experiment results in Fig. 6a and b shows the electrical and thermal efficiency versus the surface temperature and mass flow rate for Spiral flow absorber collector. The result shows that when mass flow rate increases, the surface temperature decrease and at the same time the efficiencies for electrical and thermal increase. In this experiment, the data shows that at the surface temperature of $55^{\circ} \mathrm{C}$ and mass flow rate of $0.011 \mathrm{~kg} \mathrm{sec}{ }^{-1}$, the absorber collector generates combined $\mathrm{PV} / \mathrm{T}$ efficiency of $64 \%$, with electrical efficiency of $11 \%$.

Figure $7 \mathrm{a}$ and $\mathrm{b}$ shows the electrical and thermal efficiency versus the surface temperature and mass flow rate for the Single pass rectangular tunnel absorber collector. The result is similar to the Spiral flow absorber collector. For Single pass rectangular tunnel absorber collector, at a surface temperature of $39^{\circ} \mathrm{C}$ and mass flow rate of $0.0754 \mathrm{~kg} \mathrm{sec}{ }^{-1}$, generates combined $\mathrm{PV} / \mathrm{T}$ efficiency of $55 \%$, with electrical efficiency of $10 \%$.

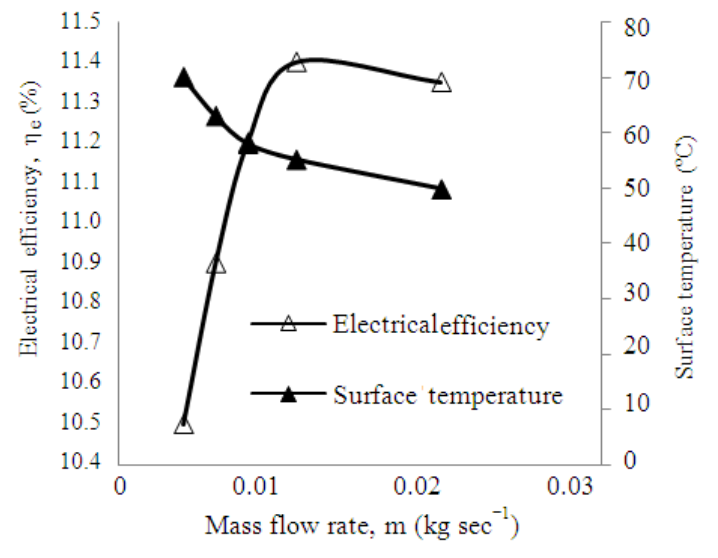

Fig. 6a: Electrical efficiency and surface temperature versus mass flow rate for Spiral flow absorber collector

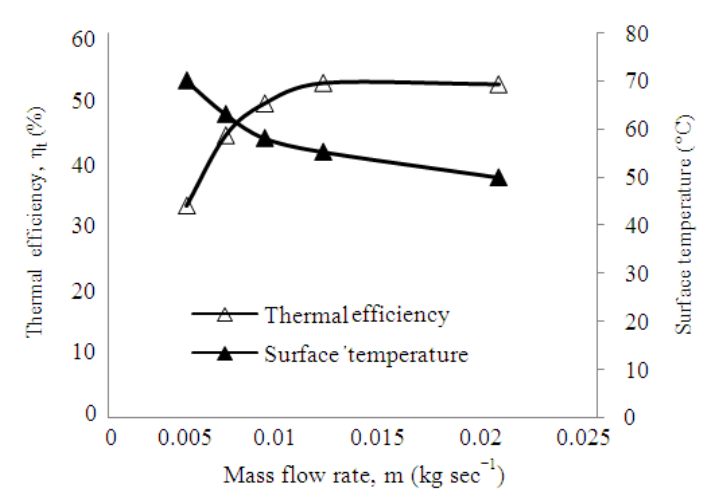

Fig. 6b: Thermal efficiency and surface temperature versus mass flow rate for Spiral flow absorber collector

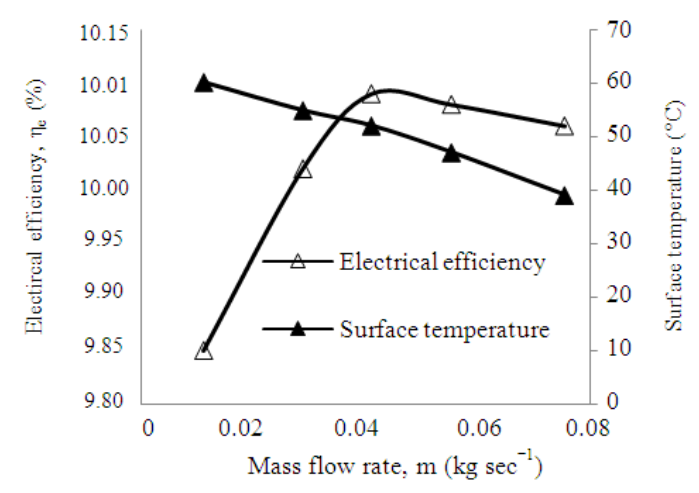

Fig. 7a: Electrical efficiency and surface temperature versus mass flow rate for Single pass rectangular tunnel absorber collector

Figure $8 \mathrm{a}$ and $\mathrm{b}$ show the dependence of electrical, thermal and combined PV/T efficiency on the mass 
flow rate of the Spiral flow and Single pass rectangular tunnel absorber collector respectively. The efficiencies approach steady state values as the mass flow rate increases. In this experiment, it is seen that for Single pass rectangular collector absorber, the steady state efficiency is reached at a threshold mass flow rate of $0.0754 \mathrm{~kg} \mathrm{sec}^{-1}$ while for Spiral flow absorber collector; the threshold mass flow rate is $0.011 \mathrm{~kg} \mathrm{sec}^{-1}$.

For Spiral flow absorber collector, the error analysis for mass flow rate at $0.011 \mathrm{~kg} \mathrm{sec}^{-1}$ was $\pm 0.004 \mathrm{~kg} \mathrm{sec}^{-1}$, error analysis for electrical efficiency was $11 \pm 3.36 \%$ and thermal efficiency was $52 \pm 0.10 \%$. For Single pass rectangular collector absorber, the error analysis for mass flow rate at $0.075 \mathrm{~kg} \mathrm{sec}^{-1}$ was $\pm 0.0052 \mathrm{~kg} \mathrm{sec}^{-1}$, error analysis for electrical efficiency was $10 \pm 4.04 \%$ and thermal efficiency was $45 \pm 0.28 \%$.

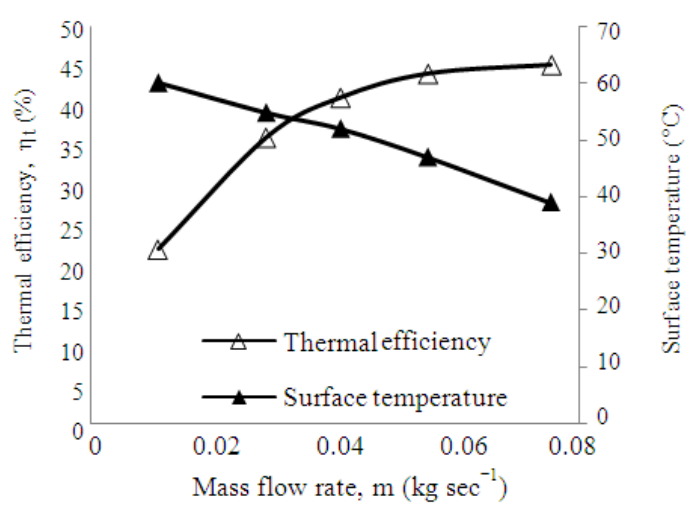

Fig. 7b: Thermal efficiency and surface temperature versus mass flow rate for Single pass rectangular absorber collector

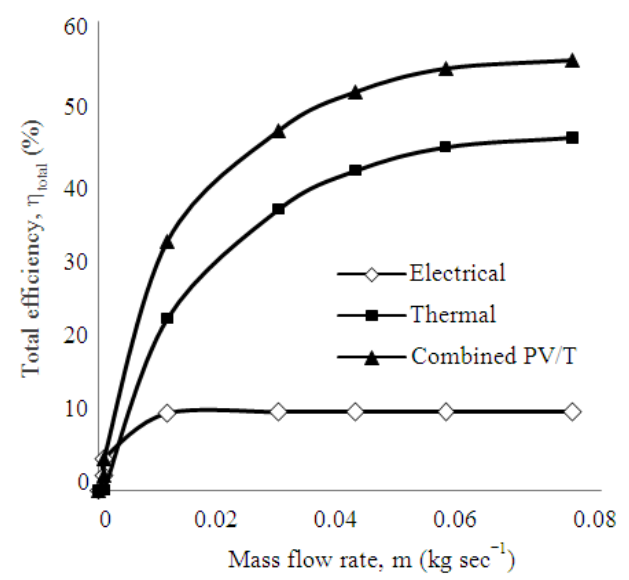

Fig. 8a: Combined PV/T efficiency versus various mass flow rates for Single pass rectangular tunnel absorber collector
Error analysis for thermal efficiency was lower then electrical efficiency and its because the mass flow rate used in thermal calculation had smaller error compare to current and voltage used in electrical.

The behaviour of the I-V curve for the two collectors is shown in Fig. 9 along with the bare plate solar panel for comparison purposes. This can be explained based on the experimental observations given in Fig. 6a and $\mathrm{b}$ and $7 \mathrm{a}$ and $\mathrm{b}$. The open circuit voltage $\left(\mathrm{V}_{\mathrm{oc}}\right)$, short circuit current $\left(\mathrm{I}_{\mathrm{sc}}\right)$ of the Spiral flow absorber collector are the highest because of the low surface temperature of the panel due to the medium used. For Single pass rectangular tunnel, the short circuit current $\left(\mathrm{I}_{\mathrm{sc}}\right)$ is less than the one in Spiral flow absorber collector but the open circuit voltage $\left(\mathrm{V}_{\mathrm{oc}}\right)$ is about the same.

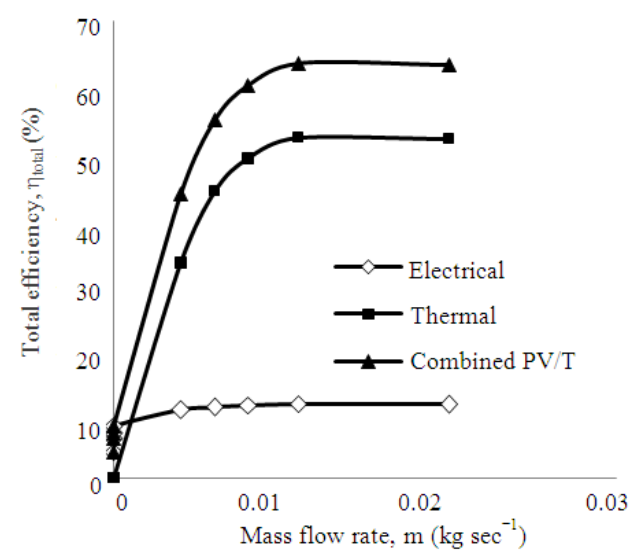

Fig. 8b: Combined PV/T efficiency versus various mass flow rates for Spiral flow absorber collector

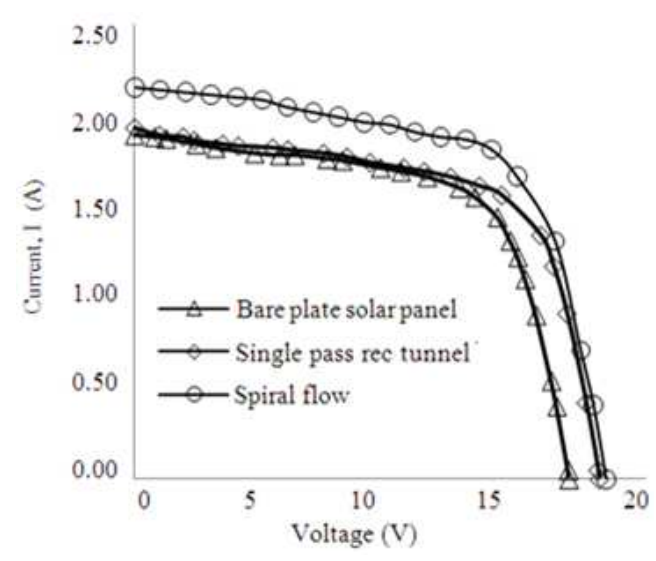

Fig. 9: I-V curve for Bare plate solar panel, Single pass rectangular tunnel and Spiral flow absorber collector 
This is due to the slightly lower temperature of the medium used giving rise to a lower surface temperature of the panel. From the observation, the result shows that the Spiral flow design collector has the power maximum of $25.35 \mathrm{~W}$ and the Single pass rectangular tunnel absorber design with tunnel have the maximum power of $22.45 \mathrm{~W}$. Both collectors are being compared to a bare plate solar panel that giving a power maximum of only $20.66 \mathrm{~W}$.

\section{CONCLUSION}

The photovoltaic solar collector comprises of a combined photovoltaic module (PV) and an absorber collector for building integrated Photovoltaic Thermal (PV/T) application, have been integrated. The optimum operating temperature of the photovoltaic module and efficiency conversion have been obtained, determined and maintained.

From this experiment, the results indicated that Spiral flow absorber collector at temperature of $55^{\circ} \mathrm{C}$ (Panel temperature), achieving the best mass flow rate at $0.011 \mathrm{~kg} \mathrm{sec}$ and generates combined $\mathrm{PV} / \mathrm{T}$ efficiency of $64 \%$, with $11 \%$ of electrical efficiency and power maximum of $25.35 \mathrm{~W}$.

Single pass rectangular collector absorber achieved it best mass flow rate at $0.0754 \mathrm{~kg} \mathrm{sec}{ }^{-1}$, at surface temperature of $392^{\circ} \mathrm{C}$, generates combined $\mathrm{PV} / \mathrm{T}$ efficiency of $55 \%$, with $10 \%$ of electrical efficiency and maximum power of $22.45 \mathrm{~W}$.

It is recommended for PV/T system to further improve its efficiency by optimizing the contact surfaces between the solar panel (photovoltaic module) and the tubes underneath.

It is also recommended to use other type of photovoltaic cell such as amorphous silicon cell that posses the black mat surfaces property that will improve it thermal absorption.

\section{REFERENCES}

1. Sadorsky, P., 1999. Oil price shocks and stock market activity. Energy Econ., 21: 449-469. http://ideas.repec.org/a/eee/eneeco/v21y1999i5p44 9-469.html

2. Azhari, A.W., K. Sopian, A. Zaharim and M. Al Ghoul, 2008. A new approach for predicting solar radiation in tropical environment using satellite images-case study of Malaysia. WSEAS. Trans. Environ. Dev., 4: 373-377. http://pkukmweb.ukm.my/ upak/pdffile/drazami/3 0-870N.pdf
3. Böer, K.W. and G. Tamm, 2003. Solar conversion under consideration of energy and entropy. Solar Energy, 74: 525-528. http://cat.inist.fr/?aModele $=$ afficheN\&cpsidt $=1514$ 8135

4. Bazilian, M.D., 2002. Photovoltaic cogeneration in the built environment. Fuel Energy Abst., 43: 269-269. DOI: $10.1016 / \mathrm{S} 0038-092 \times(01) 00005-6$

5. Garg, H.P. and R.K. Agarwal, 1995. Some aspects of a PV/T collector/forced circulation flat plate solar water heater with solar cells. Energy Conver. Manage., 36: 87-99. http://cat.inist.fr/?aModele $=$ afficheN\&cpsidt $=3390$ 985

6. Tripanagnostopoulos, Y., T. Nousia, M. Souliotis and P. Yianoulis, 2002. Hybrid photovoltaic/thermal solar systems. Solar Energy, 72: 217-234.

http://cat.inist.fr/?aModele $=$ afficheN\&cpsidt $=1352$ 7226

7. Tonui, J.K. and Y. Tripanagnostopoulos, 2008. Performance improvement of PV/T solar collectors with natural air flow operation. Solar Energy, 82: $1-12$.

http://cat.inist.fr/?aModele=afficheN\&cpsidt=2003 1666

8. Ibrahim, A., M.Y. Othman, M.H. Ruslan, M.A. Alghoul, M. Yahya, A. Zaharim and K. Sopian, 2009. Performance of photovoltaic thermal collector (PVT) with different absorbers design. WSEAS. Trans. Environ. Dev., 5: 321-330. http://www.wseas.us/elibrary/transactions/environment/2009/31-968.pdf

9. Niccolo, A., C. Giancarlo and V. Francesco, 2007. Design, development and performance monitoring of a Photovoltaic-Thermal (PVT) air collector. Renew. Energy, 10: 6-22. DOI: 10.1016/j.renene.2007.06.022

10. Wolf, Martin, 1976. Performance analyses of combined heating and photovoltaic power systems for residences. Energy Conver., 16: 79-90. http://adsabs.harvard.edu/abs/1976enco...16...79

11. Florschuetz, L.W., 1979. Extension of the HottelWhillier model to the analysis of combined photovoltaic/thermal flat plate collectors. Solar Energy, 22: 361-366. DOI: 10.1016/0038092X(79)90190-7

12. Zondag, H.A., 2008. Flat-plate PV-Thermal collectors and systems: A review. Renew. Sustain. Energy Rev., 12: 891-959. http://cat.inist.fr/?aModele $=$ afficheN\&cpsidt $=1837$ 7278 
13. Bergene Trond and Ole Martin Lovvik, 1995. Model calculations on a flat-plate solar heat collector with integrated solar cells. Solar Energy, 55: 453-462.

http://cat.inist.fr/?aModele $=$ afficheN\&cpsidt=2951 131

14. Huang, B.J., T.H. Lin, W.C. Hung and F.S. Sun, 2001. Performance evaluation of solar photovoltaic/thermal systems. Solar Energy, 70: 443-448.

http://cat.inist.fr/?aModele $=$ afficheN\&cpsidt $=9482$ 19
15. Wei, H., T.T. Chow, J. Ji, J. Lu, G. Pei and L.S. Chan, 2006. Hybrid photovoltaic and thermal solar-collector designed for natural circulation of water. Applied Energy, 83: 199-210. http://cat.inist.fr/?aModele $=$ afficheN\&cpsidt $=1751$ 6789

16. Vokas, G., N. Christandonis and F. Skittides, 2006. Hybrid photovoltaic-thermal systems for domestic heating and cooling-A theoretical approach. Solar Energy, 80: 607-615. http://cat.inist.fr/?aModele $=$ afficheN\&cpsidt $=1777$ 3328 